\title{
PTPRE wt Allele
}

National Cancer Institute

\section{Source}

National Cancer Institute. PTPRE wt Allele. NCI Thesaurus. Code C49533.

Human PTPRE wild-type allele is located within $10 \mathrm{q} 26$ and is approximately $179 \mathrm{~kb}$ in length. This allele, which encodes receptor-type tyrosine-protein phosphatase epsilon protein, is involved in the dephosphorylation of protein-tyrosine phosphates. 